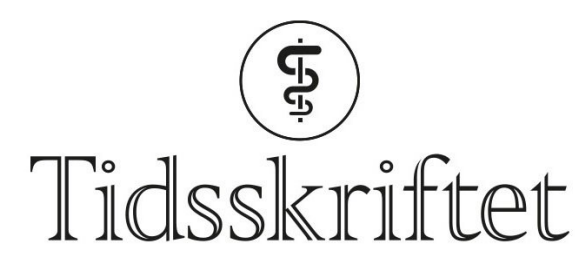

DEN NORSKE LEGEFORENING

\title{
Arbeidsrelatert håndeksem
}

KOMMENTAR

JOSE HERNÁN ALFONSO

E-post: jose.alfonso@stami.no

Jose Hernán Alfonso er overlege ved Avdeling for arbeidsmedisin og epidemiologi, Statens arbeidsmiljøinstitutt.

\section{TERESA LøVOLD BERENTS}

Ingen av forfatterne har oppgitt interessekonflikter.

Figurtekst til Figur 2 i vår artikkel er ikke korrekt (1). Korrekt undertekst skal være: «Figur 2. Eksempel på kontakteksem hos en frisør».

Bildet kan representere ulike varianter av håndeksem uavhengig av etiologi. Klinisk er det ingen klar sammenheng mellom håndeksemets morfologi og etiologi. Efflorescensene er ikke riktig beskrevet. Vi beklager denne feilen.

\section{LITTERATUR:}

1. Kvam MS, Alfonso JH, Berents TL et al. Arbeidsrelatert håndeksem. Tidsskr Nor Legeforen 2019; 139 . doi: 10.4045/tidsskr.18.0213. [PubMed][CrossRef]

Publisert: 24. juni 2019. Tidsskr Nor Legeforen. DOI: 10.4045/tidsskr.19.0395

(C) Tidsskrift for Den norske legeforening 2020. Lastet ned fra tidsskriftet.no 